\section{BRSMG Uai: common bean cultivar with carioca grain type and upright plant architecture}

\author{
Magno Antonio Patto Ramalho ${ }^{1}$, Ângela de Fátima Barbosa \\ Abreu $^{2 *}$, José Eustáquio de Souza Carneiro ${ }^{3}$, Leonardo Cunha \\ Melo ${ }^{2}$,Trazilbo José de Paula Júnior ${ }^{4}$, Helton Santos Pereira², \\ Maria José Del Peloso', Israel Alexandre Pereira Filho5, Mau- \\ rício Martins ${ }^{6}$, Marcos Paiva Del Giúdice ${ }^{3}$ and Rogério Faria \\ Vieira ${ }^{4}$
}

\begin{abstract}
The common bean cultivar with carioca grain type, BRSMG Uai, is recommended for cultivation in Minas Gerais and stands out for its upright plant architecture, which facilitates cultivation and mechanical harvesting. This cultivar has high yield potential and is resistant to the major races of anthracnose that occur in region.
\end{abstract}

Key words: Breeding, Phaseolus vulgarisL.,grain yield, disease resistance.

\section{INTRODUCTION}

Beans are among the main foods of the Brazilian population, with a consumption of $16 \mathrm{~kg} /$ inhabitant/year. Beans are important in human nutrition because they are important sources of protein and are rich in several minerals. Brazil is also a leading producer of beans. From 1993 to 2012, bean production increased by $13 \%$, despite a reduction in planting area. This increase was due to a $62 \%$ increase in the average yield (Wander 2014). Part of this increase in yield was due to the genetic breeding of this crop.

Common beans with carioca grain (beige with a brown stripe) are preferred by consumers in Brazil. Therefore, breeding programs in Brazil have developed new lines with this grain type that combine good yield and resistance to stresses, including biotic stresses (Carvalho et al. 2013, Carbonell et al. 2014). However, there is an increasing demand related to plant architecture. The desired plants are erect, which facilitates cultivation and mechanical harvesting. This architecture also decreases disease severity by providing greater air circulation between plants and provides a better-quality grain because the pods are not in contact with the ground.

To meet the needs of bean producers, institutions working in partnership in the genetic improvement of common bean in Minas Gerais (Embrapa Rice and Beans, Agricultural Research Company of Minas Gerais (Epamig), Federal University of Lavras (UFLA) and Federal University of Viçosa (UFV)) have registered BRSMG Uai, which is a new common bean cultivar with a carioca grain type and upright plant architecture that is suitable for cultivation in the state of Minas Gerais.
Crop Breeding and Applied Biotechnology 16: 261-264, 2016 Brazilian Society of Plant Breeding. Printed in Brazil http://dx.doi.org/10.1590/1984$70332016 \mathrm{v} 16 \mathrm{n} 3 \mathrm{c} 40$

\section{*Corresponding author: E-mail: angela.abreu@embrapa.br}

Received: 07 April 2016 Accepted: 08 June 2016

\footnotetext{
${ }^{1}$ Universidade Federal de Lavras (UFLA), Departamento de Biologia, C.P. 3037, 37.200000, Lavras, MG, Brazil

${ }^{2}$ Embrapa Arroz e Feijão, Rod. GO-462, km 12, Zona Rural, C.P. 179, 75.375-000, Santo Antônio de Goiás, GO, Brazil

${ }^{3}$ Universidade Federal de Viçosa (UFV), Departamento de Fitotecnia, 36.570-000, Viçosa, MG, Brazil ${ }^{4}$ Empresa de Pesquisa Agropecuária de Minas Gerais (Epamig), Av. José Cândido da Silveira, 1647, União, 31.170-495, Belo Horizonte, MG,

Brazil

${ }^{5}$ Embrapa Milho e Sorgo, Rod. MG-424, km 45, Sete Lagoas, C.P. 285, 35.701-970, Sete Lagoas, MG, Brazil

${ }^{6}$ Universidade Federal de Uberlândia (UFU), 38.400-902, Uberlândia, MG, Brazil
} 


\section{BREEDING METHODS}

The cultivar BRSMG Uai was obtained by hybridization in a recurrent selection program that aimed to obtain progenies with the carioca grain type, in association with upright plant architecture and high yields. In 2001, we performed a diallel cross among ten common bean inbred lines with upright plant architecture (Carioca MG, CNFC 9454, CNFC 9455, CNFC 9458, CNFC 9466, CNFC 9471, CNFC 9484, IAPAR 81, 9876 LP and IPR Uirapuru). The seeds of the 42 hybrids of the $F_{1}$ generation were sown to obtain the $F_{2}$ generation.The $42 F_{2}$ populations were assessed for grain yield, with sowing in February 2002 in Lavras, MG, Brazil. Of these 42 populations, the 11 most promising were chosen to form the base population $\left(\mathrm{S}_{0}\right)$ of the first cycle $\left(\mathrm{C}_{0}\right)$. From these populations, 190 individual plants were selected, which gave rise to 190 progenies. These progenies were evaluated in the $S_{0: 1}, S_{0: 2^{\prime}} S_{0: 3^{\prime}}, S_{0: 4}$ and $S_{0: 5}$ generations from July 2002 to May 2004 and were selected for grain yield, grain type and plant architecture. In all generations, the progenies were assessed by the bulk method. In generation $\mathrm{S}_{0: 5}$, the selected progeny received the designations RP-1 and, subsequently, BRSMG Uai.

Line RP-1 was assessed in the experiments of elite lines of the Common Bean Breeding Program of UFLA, along with other 31 lines and five control cultivars (Carioca, Carioca MG, Pérola, BRSMG Talismã and Ouro Negro) in crop seasons with sowing in November 2004, February 2005, July 2005, November 2005, February 2006 and July 2006. Experiments

Table 1. Mean grain yield ( $\mathrm{kg} \mathrm{ha}^{-1}$ ) of the cultivar BRSMG Uai and controls (BRSMG Talismã and Pérola) per location, sowing month and year of assessment in the state of Minas Gerais.

\begin{tabular}{|c|c|c|c|c|c|c|}
\hline \multirow[t]{2}{*}{ Location } & \multirow{2}{*}{ Sowing month } & \multirow[t]{2}{*}{ Year } & \multirow{2}{*}{$\begin{array}{c}\text { BRSMG } \\
\text { Uai }\end{array}$} & \multicolumn{2}{|c|}{ Controls } & \multirow{2}{*}{$\%$ of the controls mean } \\
\hline & & & & BRSMG Talismã & Pérola & \\
\hline Lavras & July & 2007 & 2650 & 2467 & 2016 & 118.2 \\
\hline Lambari & July & 2007 & 1340 & 1385 & 1541 & 91.6 \\
\hline Patos de Minas & July & 2007 & 2158 & 2058 & 1675 & 115.6 \\
\hline Sete Lagoas & July & 2007 & 3200 & 3200 & 2933 & 104.4 \\
\hline Coimbra & July & 2007 & 3187 & 2451 & 3170 & 113.4 \\
\hline Formoso & May & 2007 & 1170 & 1053 & 1139 & 106.8 \\
\hline Lavras & November & 2007 & 2400 & 2650 & 2238 & 98.2 \\
\hline Lambari & November & 2007 & 1912 & 1467 & 1800 & 117.0 \\
\hline Coimbra & November & 2007 & 3418 & 3218 & 3014 & 109.7 \\
\hline Lavras & February & 2008 & 2554 & 2250 & 2562 & 106.2 \\
\hline Lambari & February & 2008 & 2575 & 1883 & 2300 & 123.1 \\
\hline Patos Minas & February & 2008 & 2004 & 1867 & 1717 & 111.8 \\
\hline Uberlândia & February & 2008 & 1603 & 1802 & 1738 & 90.6 \\
\hline Florestal & February & 2008 & 3514 & 3105 & 3514 & 106.2 \\
\hline Oratórios & February & 2008 & 2229 & 1460 & 1581 & 146.6 \\
\hline Formoso & May & 2008 & 1399 & 1591 & 1605 & 87.5 \\
\hline Sete Lagoas & July & 2008 & 3575 & 3900 & 3330 & 98.9 \\
\hline Uberlândia & May & 2008 & 2219 & 1964 & 2464 & 100.2 \\
\hline Coimbra & July & 2008 & 3654 & 1681 & 2904 & 159.4 \\
\hline Lavras & November & 2008 & 1345 & 1105 & 1358 & 109.2 \\
\hline Lambari & November & 2008 & 2100 & 1392 & 1475 & 146.5 \\
\hline Patos de Minas & November & 2008 & 2725 & 2332 & 2770 & 106.8 \\
\hline Uberlândia & November & 2008 & 1504 & 1553 & 1410 & 101.5 \\
\hline Patos Minas & February & 2009 & 2095 & 2192 & 2638 & 86.7 \\
\hline Viçosa & February & 2009 & 2307 & 2272 & 2500 & 96.7 \\
\hline Uberlândia & February & 2009 & 2439 & 2962 & 2769 & 85.1 \\
\hline Uberlândia & May & 2009 & 2362 & 3322 & 3070 & 73.9 \\
\hline Coimbra & July & 2009 & 2477 & 2243 & 2361 & 107.6 \\
\hline Mean sowing February & & & 2369 & 2199 & 2369 & 103.7 \\
\hline Mean sowing May-July & & & 2449 & 2276 & 2362 & 105.6 \\
\hline Mean sowing November & & & 2201 & 1960 & 2009 & 110.9 \\
\hline General mean & & & 2361 & 2172 & 2271 & 106.3 \\
\hline
\end{tabular}


were carried out in Lavras and Lambari, southern Minas Gerais, and in Patos de Minas, Alto Paranaiba Region. A joint analysis of grain yield and other agronomic traits suggested that line RP-1 should be chosen to participate inValues for Cultivation and Use (VCU) trials in Minas Gerais.

RP-1 was assessed in VCU trials that were carried out from May 2007 until November 2009 in 28 environments in the state (Table 1). This line was evaluated along with 23 others and with the control cultivars BRSMG Talismã and Pérola. The experiments were arranged in a randomized complete block design, with three replications and plots consisting of four 4-m rows. The following traits were evaluated: grain yield $\left(\mathrm{kg} \mathrm{ha}^{-1}\right)$; severity of angular leaf spot on a scale from 1-9, where 1 denotes a plant without disease symptoms and 9 indicates a completely infected plant (Schoonhoven and Pastor-Corrales 1987), considering resistant lines to be those with an average score up to 3 and susceptible lines to be those with an average score above 3; plant architecture, on a scale from 1-9, where 1 denotes upright plants and 9 indicates completely prostrate plants (Melo 2009); and degree of lodging, on a scale from 1-9, where 1 indicates an absence of lodging and 9 indicates all plants lodged (Melo 2009).

The reaction to races $65,73,81$ and 89 of Colletotrichum lindemuthianum, which is the fungus that causes anthracnose, was evaluated in the laboratory according to the methodology described by Rava et al. (1994), as were the reaction to the common mosaic virus; the reaction to the fungus Fusarium oxysporum, which is the causal agent of fusarium wilt; the cooking time (in minutes) in a 25-seed Mattson cooker (Proctor and Watts 1987); and the protein content based on the total nitrogen grain content, as determined by the micro Kjedahl method using the factor 6.25 to convert the total $\mathrm{N}$ to protein (Horwitz 1980).

\section{CULTIVAR CHARACTERISTICS}

\section{Plant architecture and lodging resistance}

The cultivar BRSMG Uai has an indeterminate, type II growth habit. In the evaluations of plant architecture and lodging tolerance on a rating scale, the performance of BRSMG Uai was superior to that of BRS Estilo, which also has an erect architecture and is already recommended and widely accepted for cultivation in Brazil (Table 2) (Melo et al. 2010). Because it has taller plants and the tallest aboveground pod, 'BRSMG Uai' is adapted for direct mechanical harvesting, with fewer losses during this process.

\section{Disease response}

In assessments by artificial inoculation in a greenhouse, BRSMG Uai showed resistance to the races $65,73,81$ and 89 of anthracnose, which are most frequently found in common bean crops in Brazil (Table 2).In addition, under controlled conditions, BRSMG Uai showed resistance to the common mosaic virus. In evaluations performed in the field, BRSMG Uai was susceptible to angular leaf spot and, in areas with a highly controlled infestation of Fusarium oxysporum, showed moderate resistance to fusarium wilt.

\section{Crop cycle}

The flowering of the cultivar BRSMG Uai occurs, on average, 46 days after sowing. The crop cycle is similar to that of BRS Estilo and can be considered normal, ranging from 85 to 95 days from sowing to harvest, depending on the season and region.

\section{Grain yield}

The cultivar BRSMG Uai presented a grain yield that was $6.3 \%$ greater than the average of the controls Pérola

Table 2. Some traits of the cultivar BRSMG Uai and control BRS Estilo obtained in the VCU trials conducted in the state of Minas Gerais in the years 2007-2009 and under controlled conditions carried out at Embrapa Rice and Beans.

\begin{tabular}{lcc}
\hline Trait & BRSMG Uai & BRS Estilo \\
\hline Plant architecture $^{1}$ & 2.0 & 3.4 \\
Lodging $^{2}$ & 2.6 & 4.0 \\
Days until maturity $_{\text {Angular leaf spot }}{ }^{3}$ & 85 & 87 \\
Anthracnose $^{3}$ & $\mathrm{~S}$ & $\mathrm{~S}$ \\
$\quad$ & & \\
$\quad$ Pathotype 65 & $\mathrm{R}$ & $\mathrm{S}$ \\
$\quad$ Pathotype 73 & $\mathrm{R}$ & $\mathrm{S}$ \\
$\quad$ Pathotype 81 & $\mathrm{R}$ & $\mathrm{S}$ \\
$\quad$ Pathotype 89 & $\mathrm{R}$ & $\mathrm{R}$ \\
Fusarium wilt $^{3}$ & $\mathrm{MR}$ & $\mathrm{S}$ \\
Common mosaic virus $^{3}$ & $\mathrm{R}$ & $\mathrm{R}$ \\
100 seed weight(g) & 24 & 26 \\
Cooking time (minutes) & 32 & 26 \\
Protein (\%) & 20 & 23 \\
\hline
\end{tabular}

${ }_{1}^{1}$ Scale from 1-9, where 1 denotes upright plants and 9 indicates completely prostrate plants; ${ }^{2}$ Scale from 1-9, where 1 indicates an absence of lodging and 9 indicates all plants lodged; ${ }^{3}$ Reactiontodisease: R - resistant; MR - moderately resistant; $S$ - susceptible. 
and BRSMG Talismã when considering the average of all locations and seasons (Table 1).This value was higher than the average of the controls in the three sowing seasons but was most prominent in sowing performed in November, with a superiority of approximately $11 \%$. Combined with the higher yield during this crop season, it the advantage that BRSMG Uai presents by having erect plants should once again be emphasized. When sowing is carried out in November, the harvest occurs in January, at which usually the rainfall is intense in the region. In prostrate plants, the pods can come into contact with moist soil and thus affect grain productivity and quality, which does not occur in BRSMG Uai.

\section{Industrial and technical grain quality}

Cultivar BRSMG Uai has a carioca grain type, with an average 100 -seed weight of $24 \mathrm{~g}$. The cooking time is 32 minutes, and the protein content is $20 \%$, which are comparable to those of most currently recommended bean cultivars (Table 2).

\section{BASIC SEED PRODUCTION}

Cultivar BRSMG Uai was registered by Embrapa, Epamig, UFLA, and UFV in the National Register of Cultivars (RNC) of the Brazilian Ministry of Agriculture, Livestock and Supply (MAPA) on July 31, 2015, under number 33555, and the request for protection is being analyzed by the National Plant Varieties Protection Service (SNPC). Embrapa Products and Market is in charge of the seed production.

\section{REFERENCES}

Carbonell SAM, Chiorato AF, Bolonhezi D, Barros VLNP, Borges WLB, Ticelli M, Gallo PB, Finoto EL and Santos NCB (2014) 'IAC Milênio' - Common bean cultivar with high grain quality. Crop Breeding and Applied Biotechnology 14: 273-276.

Carvalho RSB, Lima IA, Alves FC and Santos JB (2013) Selection of carioca common bean progenies resistant to white mold. Crop Breeding and Applied Biotechnology 13:172-177.

Horwitz W (1980) Official methods of analysis of the Association of Official Analytical Chemists (AOAC). $13^{\text {th }}$ edn, Association of Official Analytical Chemists, Washington, 1018p.

Melo LC (2009) Procedimentos para condução de ensaios de valor de cultivo e uso em feijoeiro-comum. Embrapa Arroz e Feijão, Santo Antônio de Goiás, 104p.

Melo LC, Del Peloso MJ, Pereira HS, Faria LC, Costa JGC,Diaz JLC, Rava
CA, Wendland A and Abreu AFB (2010) BRS Estilo - Common bean cultivar with carioca grain, upright growth and high yield potential. Crop Breeding and Applied Biotechnology 10: 377-379.

Proctor JR and Watts BM (1987) Development of a modified Mattson bean cooker produce based on sensory panel cookability evaluation. Canadian Institute of Food Science andTecnology 20: 9-14.

Rava CA, Purchio AF andSartorato A (1994) Caracterização de patótipos de Colletotrichumlindemuthianumque ocorrem em algumas regiões produtoras de feijoeiro comum. Fitopatologia Brasileira 19: 167-172.

Schoonhoven A and Pastor-Corrales MA (1987) Standard system for the evaluation of bean germoplasm. CIAT, Cali. 54p.

Wander AE (2014) Socioeconomia. In Ramalho MAP, Abreu AFB and Guilherme SR (Eds) Informações técnicas para o cultivo do feijoeirocomum na Região Central-Brasileira: 2015-2017. UFLA, Lavras, p. 15-35. 